\title{
The geographical position, system and modelling of golf tourism
}

\author{
RóbeRt KISS ${ }^{1}$
}

\begin{abstract}
This paper aims to present the spatial assumptions related to the tourism theory and the geographical correlations of golf tourism. It attempts to define the concept and to study golf as a tourism product in a systemic approach: it presents its internal and external environment. In the first place, golf courses being the most important factor of golf tourism and the interconnection of other supply elements are discussed. In the second place, the paper highlights the role of the intermediary sector specialised in satisfying golf-related special needs. In the third place, it describes the characteristic features of golf demand. It presents the Western European, Mediterranean and Central European regions (the most preferred areas of research), and it establishes the theory of $\mathrm{ABC}$ golf destinations in the Mediterranean region, i.e. tourism supply elements in a unique spatial arrangement. The research results include the interpretation of Maslow's hierarchy of motivational needs from the golfers' approach, which helps us understand the golfers' decision-making process and the stages thereof. Based on the theory, the author establishes the golf ball model of the interconnected material conditions of tourism in which the layers of the basic, infra- and suprastructure required for golf tourism are interconnected like the concentric shells of a sphere.
\end{abstract}

Keywords: golf, model, tourism, system, geography

\section{Introduction}

The topicality of researching and spatially mapping of golf tourism in Hungary is given by the fact that although golf is one of the most popular and most widely played sports in the world, in Hungary it is regarded as an overly stereotyped, mystified, hardly-known recreational activity of foreign origin, and as such, its value as a sport is considerably questioned. It is partly due to this approach that Hungarian scholars have never or have hardly dealt with that niche area of sport tourism.

${ }^{1}$ Department of Tourism, Kodolányi János University of Applied Sciences, H-8000 Székesfehérvár, Sörház tér 1. E-mail: robertkiss@kodolanyi.hu 
Most of the publications released on golf and golf tourism so far are surveys linked to active tourism (Szonda Ipsos 2000; RáTz, T. and KIss, R. 2007) researching materials on the demand for and the supply of golf opportunities in Hungary (RÁtz, T. and KIss, R. 2010) and investigating golf as an Olympic sport (BARÁTH, K. et al. 2011). The small number of publications, in itself, indicates that golf is underrepresented among the Hungarian tourism products in terms of research. In contrast, the international literature shows that plenty of surveys have been conducted on golf demand and supply in destinations heavily affected by golf tourism (Рetrick, J.F. et al. 2001; Correia, M. and Pintassilgo, P. 2006; Kim, S.S. et al. 2005; Wilson, J. and Thilmany, D. 2006) and on the elements of infra- and suprastructure required for receiving players. publications presenting golf tourism in its entirety have been also released (Hudson, S. and Hudson, L. 2010).

\section{The definition of golf tourism}

Finding a definition to golf is as difficult as finding one for tourism, since first we need to resolve the golfers' dilemma: some regard golf as a sport, some regard it as a leisure activity, others consider it as a type of community lifestyle, and a smaller number of people regard it as an element of belonging to a club, a certain community. According to many, golf is a combination of the above in varying proportions. Golfers are motivated by several factors, the common thing being crave for enjoyment through golf. Most people regard golf as a leisure activity, but there are also many who play golf within the framework of business tourism.

The definition of golf tourism must be started with a short review of foreign literature so that golf tourism can be presented in a systemic approach. According to the authors Hudson, S. and Hudson, L. (2010), who teamed up to publish the first separate book on golf tourism, golf tourism is a branch of sport tourism, one of the most rapidly developing fields of tourism as a whole.

It was Robinson, T. and Gammon, S. (2004) who attempted to sum up golf tourism in a framework typical for sport tourism built on motivation. As such, they distinguished between golf sport tourism and golf tourism sport. They identified a soft and hard subtype in each case (Hudson, S. and Hudson, L. 2010) (Table 1).

While the hard definition of golf sport tourism means active or passive participation (player or spectator) in competitive sporting events (e.g. Ryder Cup, USA Masters, British Open, European Tour, American PGA Tour, etc.), the soft definition of golf as a sport is about active participation for recreational purposes (such as visiting golf resorts, cruises and schools).

The common characteristic feature of golf tourism sport is the primary motivation of travelling. According to its hard definition, the term pertains to visitors whose engagement in some minor form of sport or leisure as a 
Table 1. Application of the sport tourism and tourism sport theory to golf

\begin{tabular}{|c|c|c|c|}
\hline \multicolumn{4}{|c|}{ Golf Sport and Tourism } \\
\hline \multicolumn{2}{|c|}{ Golf Sport Tourism } & \multicolumn{2}{|c|}{ Golf Tourism Sport } \\
\hline Hard & Soft & Hard & Soft \\
\hline \multicolumn{4}{|c|}{ definition } \\
\hline $\begin{array}{l}\text { Passive or active } \\
\text { participation is a } \\
\text { competitive sport- } \\
\text { ing event }\end{array}$ & $\begin{array}{l}\text { Primarily active } \\
\text { recreational partici- } \\
\text { pation in sport }\end{array}$ & $\begin{array}{l}\text { Visitors who en- } \\
\text { gage in some minor } \\
\text { form of sport or } \\
\text { leisure, their par- } \\
\text { ticipation is purely } \\
\text { incidental. Includes } \\
\text { all golf related } \\
\text { facilities a tourist } \\
\text { may encounter }\end{array}$ & $\begin{array}{l}\text { Tourist as a sec- } \\
\text { ondary reinforce- } \\
\text { ment passively or } \\
\text { actively participate } \\
\text { in sport }\end{array}$ \\
\hline $\begin{array}{l}\text { (Ryder Cup, Walker } \\
\text { Cup, USA Masters, } \\
\text { European Tour, } \\
\text { American PGA Tour, } \\
\text { Senior Tour, British } \\
\text { Open, Amateur } \\
\text { championship, } \\
\text { LPGA, Junior events } \\
\text { etc.) }\end{array}$ & $\begin{array}{l}\text { (Golf holidays, } \\
\text { golf resorts } \\
\text { golf cruises, } \\
\text { golf schools) }\end{array}$ & $\begin{array}{l}\text { (Executive golf } \\
\text { courses, pitch and } \\
\text { putt, crazy golf, min- } \\
\text { igolf, putting, driving } \\
\text { ranges, target golf) }\end{array}$ & $\begin{array}{l}\text { (Sport resorts, hotels, } \\
\text { cottage holidays or } \\
\text { holiday villas near } \\
\text { golf courses; Visitor } \\
\text { Attractions World } \\
\text { Golf Hall of Fame, } \\
\text { Florida; British } \\
\text { Golf Museum, St. } \\
\text { Andrews, Scotland) }\end{array}$ \\
\hline
\end{tabular}

Source: Robinson, T. and Gammon, S. 2004 adapted by Hudson, S. and Hudson, L. 2010, and KIss, R. 2013

secondary motivation is purely incidental (e.g. training courses, pitch and putt, mini golf, etc.), while the soft definition relates to tourists who as a secondary reinforcement participate golf passively or actively (e.g. hotels at the golf courses, the use of resorts of villa park with golf courses, visiting to the World Golf Hall of Fame, etc.) (Hudson, S. and Hudson, L. 2010).

A similar fourfold categorisation was developed by KIss, R. and RÁtz, T. (2007) who believes that golf as a physical activity and as a part of the tourism supply can be interpreted along all dimensions described under sport tourism. Moreover, it can correspond to each alternative of all four dimensions. On one hand, golf can be a leisure activity, primarily for private recreational purposes as well as for business purposes to a smaller extent, since playing sport together with potential business partners has an important role in the development of formal relations. On the other hand, it can be a primary or secondary attraction forming part of domestic or international tourism supply. Based on the above, golf can attract players and spectators both in an active and passive form, and it can be concurrently regarded as a competitive sport and "elite mass sport", for the activity is not restricted to a small group of professional competitors. 
In harmony with the definitions presented above, the author believes that golf tourism is a sort of recreational travel away from home with the primary purpose of playing golf, and it involves accommodation booking as well as a higher spending not typical for an average tourist. All this can happen through playing golf (pursuing an active physical activity), attending a golf competition as an escort or spectator (passive participation) or visiting golfrelated attractions (a world famous golf course or a museum, etc.). An example to the latter passive activities is attending the Ryder Cup championship as a spectator or visiting St. Andrews, the Mecca of golf (Hudson, S. and Hudson, L. 2010). Playing golf is often linked to a second home or a timeshare property investment in a resort having a much more pleasant climate than the place of permanent residence, so the place of permanent residence is left behind as per the definition, and this type of travel (if it lasts for less than a year) can be regarded as golf tourism provided to those concerned with in playing golf.

Now that the author has provided his basic definition, it is reasonable to present golf tourism from the practical approach, based on the following aspects:

1. nature (leisure or business tourism)

2. form (mass tourism or alternative tourism) and

3. type (domestic or international).

In terms of nature, golf tourism can primarily be associated with recreational tourism, since tens of millions of people play golf around the world and travel regularly in order to enjoy their favourite sport. Requiring strong concentration for several hours, this outdoor physical activity can be regarded as a type of active tourism (Michalkó, G. 2002; Csapó, J. et al. 2010).

Apart from the recreational nature of golf tourism, it must be pointed out that in terms of nature, golf tourism is also considered as business tourism. Golf primarily appears as an auxiliary program of business meetings, as an invitation of fellow players to join a club or as a venue of such meetings. In the latter case, playing golf without the involvement of a referee, strictly on the basis of the rules of fair play can help to become acquainted with the potential contracting party/to learn about the personality of the negotiating party, since the behaviour demonstrated on the golf course gives you hints about his conduct in the world of business. Consequently, it can be easily determined whether you would like to cooperate with your game partner in the future, whether you consider him as a reliable person who knows and complies with the rules, or you would not like to work with him due to his unreliable personality.

At an international level, golf is a popular form of reward at certain companies or company groups either as a special programme or as part of the incentive package. It is a popular form of rewarding corporate performance in the Far East giving golf-related business bonuses, gifts and rewards (Hudson, S. and Hudson, L. 2010). Some other companies maintain golf societies serving the 
purpose of community development, keep a healthy competitive spirit and satisfy the competitive needs of avid golfer employees (competitive sport). Finally, in the case of business tourism, a company may enter into a sponsorship agreement with the club which in return, for financial support, accepts a certain number of members or it offers discount membership for a given period of time either for specific persons or for any employee of the sponsoring company.

As far as its form is concerned, golf tourism was initially regarded as a part of alternative tourism (which was not defined in the first stage of development), i.e. as an active tourism product sought after by individuals, since at the beginning, it was significant neither in supply nor in demand.

In connection with the expansion of golf, during the recent decades, it can be seen that in many cases (e.g. Turkey) radical development has been achieved with state support, and the growth of the industry is increasingly due to the rise of mass tourism (KIss, R. 2012). Especially in regions with a pleasant climate, for the better utilisation of the huge primary tourism, suprastructure developed to meet the demands of summer seaside tourists, service providers turn towards sport tourism able to create a demand even in the low season. Initially, golf course construction at seaside resorts was carried out within the framework of alternative tourism, and then having realised the economic benefits, investors started major property developments. That practice can partly be blamed for the ill-considered golf course construction projects of the 1970s-1990s which failed to take environmental considerations into account and increased the built-up ratio of seaside resorts.

The current strict environmental rules and requirements of golf course construction call for the optimum utilisation of the resources of the geographical environment, and they allow construction projects which spare the original environment to the greatest possible extent. In parallel with this, environment conscious consumption of golfers is on the rise, wherefore we can witness the development of an international golf community which involves more and more people while protecting the resources and the natural environment.

In terms of type, golf tourism can be domestic or international depending on whether the destination of the trip with golf being the primary motivation is within or outside the country. The different geographical regions are at different levels of economic and cultural development, therefore due to the different motivations of golfers, there have emerged traditional outbound (Scandinavia, Great Britain, Germany) and inbound (Spain, Portugal and Turkey) golf markets and the combinations thereof (Ireland, Scotland) with a lot of inbound and outbound golfers. One of the best examples for domestic golf tourism is the United States where the popularity of the so-called sunshine states (Florida, Georgia, South and North Carolina, Arizona, Nevada and California) can be explained with the climate similarly to that in Europe. In states above, the golf season starts in early spring, (in some places in autumn) 
and it lasts until the beginning of summer, then it resumes in autumn. In terms of statistics, domestic golf tourism seems to be less significant, however, if the high number of recreational golfers is also included, it brings stability to this segment of the tourism industry.

In terms of tourism product types, golf tourism must be classified under active tourism products as a physical activity, provided it as a free time activity. It is supported by the fact that $97-98 \%$ of the world's golfers are amateurs, most of whom play golf only within their own community as a hobby for their own pleasure and entertainment. The remaining $2-3 \%$ of golfers are professional players and/or instructors who compete and/or teach on a regular basis for which they are paid, i.e. they purely pursue sports activities to make a living.

Without making claim for completeness, it must be noted that near big cities, golf is also considered as a major recreational activity, because it offers relaxation and refreshment from everyday work without having to leave one's hometown and pay for accommodation elsewhere. In certain classic golf destinations (USA, British Isles, Japan), golf is a part of business tourism as well, but its share is insignificant compared to recreational golf, and in such cases golf is only a secondary motivation.

On the basis of the above, the typical golf tourist who aims to play on several golf courses in a destination can be linked to recreational tourism or active tourism within that. In support of this argument, it must be pointed out that Magyar Turizmus Zrt. (Hungarian National Tourist Office) listed golf tourism under the category of premium products as an atypical segment of the Hungarian active tourism programmes on offer which lacks local traditions and does not enjoy great international demand, but those involved in it spend more than an average tourist. It is a well-founded definition, since golf tourism is primarily an auxiliary segment which provides additional services, recreational opportunities (as a secondary motivation) to tourists visiting Hungary for other purposes.

\section{Methodology}

The primary aim of this publication is to share the results of the theoretical research conducted by the author in preparation for his PhD thesis (Kiss, R. 2013) which was based on the analysis of major secondary sources (statistics, development plans), the adaptation of models and correlations used in golf tourism and on the primary research. Apart from the mainly international publications, the author conducted over 60 personal interviews with Irish, Portugese, Turkish, Kenyan and Hungarian golf experts, and he presents the results, the conclusions based on the theory as well as his model in the follow- 
ing chapter. The interviewees included golf club directors, course managers, golf investors, golf instructors, golf tour operators, golfers, etc., i.e. the research covered the entire system, the supply and the demand side of golf tourism as well as the intermediary segment. The interviews were made between spring 2009 and autumn 2012, and they were supplemented with focus group questionnaires on both the supply and demand elements.

\section{Results - The system and model of golf tourism}

Tourism as a complex phenomenon and sector forming an organic part of the economy can be described with market characteristics similarly to any other industry. In other words, it equals with the open system of demand and supply interacting with its (natural, economic, social, political and technical) environment (LengyeL, M. 1992). Due to the interaction, the development of tourism is influenced by certain factors of the environment, but at the same time, tourism also affects the environment in a positive or negative manner with its processes and the development of its infra- and suprastructure. This generally accepted model ("The internal and external system of golf") is taken from LenGYeL, M. (1992), and it revised and adapted to the studied tourism product. The model also supports the assumptions about the market operation of golf tourism (Figure 1).

Presenting the definitions of tourism, it was concluded that the internal system forms the demand, i.e. the connection between golf tourists (golfers) and supply (golf courses) by the intermediate sector jointly make up the tourism market. Tourists (golfers in this case) reach a product through their primary motivation, i.e. his attraction to golf. The objective of a travel can take various shapes, because it can be significantly influenced by the marketing activity of other players of the tourism market, e.g. the intermediaries and the service providers representing the tourism supply.

An appeal can be one or more characteristics of a golf course (e.g. quality, difficulty level, reputation, designer's name, location, proximity to other golf courses, etc.) or an entire golf destination which has been tested earlier or which simply has a favourable image (Antalya-Belek). In addition to motivation, the development of the demand can be fostered by the size of disposable income and sufficient free time. The desire for travelling can be strengthened by the natural endowments, i.e. the climatic reason can be twofold: on one hand, it has a so-called push effect due to the unavailability of domestic golf courses in winters, while on the other hand, an exotic environment with a pleasant climate acts as a pull factor.

Golfers involved in international tourism are more likely to visit new courses in addition to the ones they have already played on. Thanks to this customer demand, golf destinations which have been built as a result 


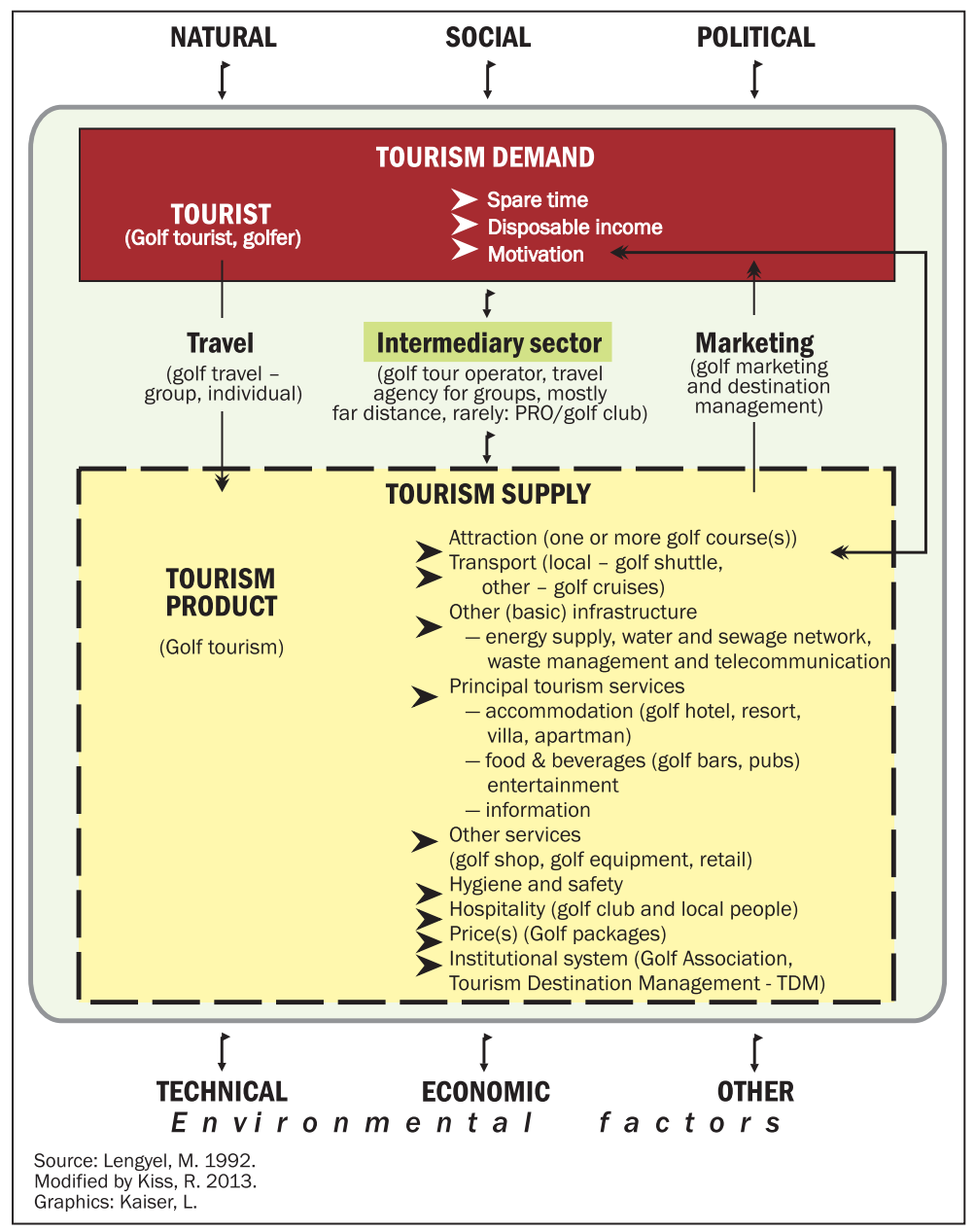

Fig. 1. The internal and external system of golf tourism. Source: Lengyel, M. 1992, modified by Kiss, R. 2013

of purposeful tourism development and have several adjacent golf courses, adequate tourism and suprastructure on Mediterranean or subtropical coasts enjoy a competitive edge. The author calls the popular geographical areas (countries, provinces, coastlines and isles) above the ABC destinations of the European (Mediterranean) golf tourism (Figure 2) on the basis of their English names which are the following:

- (A) Andalusia (Costa del Sol and Costa de la Luz) a Spanish province with a stretch of coastline; Algarve in Portugal and Antalya(-Belek) in Turkey (coastline); the African destinations of mass tourism (Morocco, Tunisia, Egypt). 


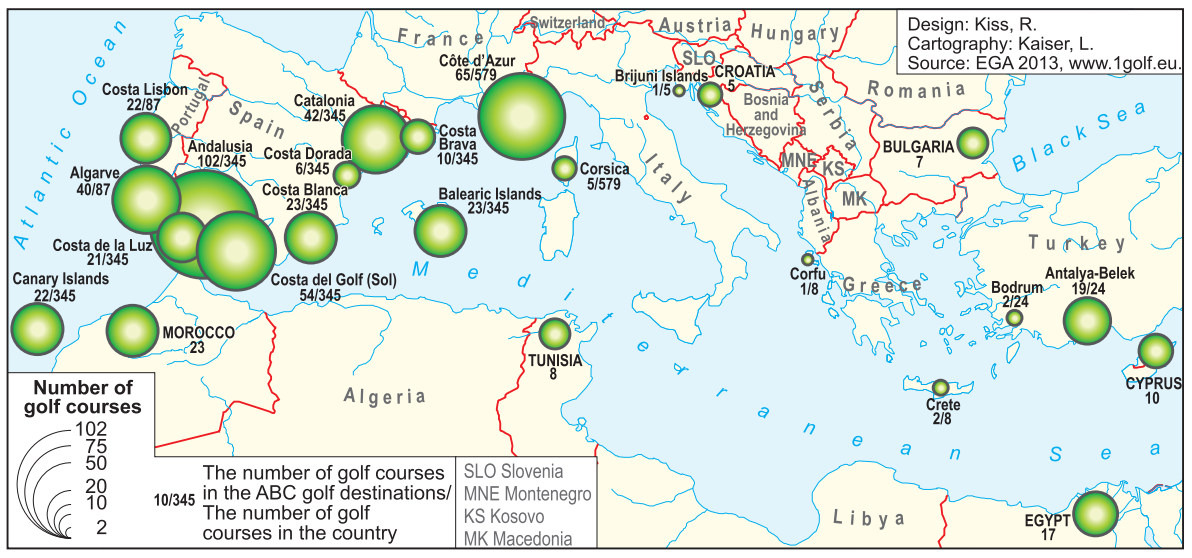

Fig. 2. The ABC golf destinations of the European (Mediterranean) golf tourism. Source: Kiss, R. 2013

- (B) From among the coastlines and islands, the Belek and Bodrum(Mugla) regions in Turkey, the Balearic Islands off Spain, the Brijuni Islands in Croatia, and as a country, Bulgaria (non-Mediterranean).

- (C) The outstanding Spanish Costa's: Costa del Sol (Golf) and Costa de la Luz (both in Andalusia), Costa Brava and Costa Dorada (both in Catalonia), Costa Blanca, Costa Lisbon in Portugal, the Côte d'Azur \& Provence in France. There are other larger and smaller islands such as the Canary Islands off Spain, the French Corsica, Corfu and Crete in Greece and there are countries as well: Croatia and Cyprus.

The $\mathrm{ABC}$ golf destinations are a good illustration of the role of climatic attractions bridging the continents. The golf regions listed above are unanimously the most popular among the international destinations (Spain, Portugal, France, Turkey, Cyprus, Morocco, Egypt), and the typical seaside areas which have not been discovered by golfers (Corsica, Crete, Corfu) have a significant growth potential despite the current insignificant supply. The Southern European regions with a pleasant climate are, first of all, recipient golf centres at the edge of the continent similarly to the African coastal region with its Mediterranean climate. Africa is mentioned here exclusively as a destination building on outbound European golf tourism, including Morocco, Tunisia and Egypt which have close ties with the outbound markets. For golfers, the Mediterranean region can be regarded as one region, because the climatic conditions are almost identical. Therefore, the choice is mostly influenced by the suprastucture of golf tourism.

In the system of golf tourism, the primary motivation for travelling is golf. Golf tourism is induced by the fact that the demand and supply elements can be found in different regions, therefore in international golf the trips usually 
for groups to places further afield are organised by a specialised intermediary sector (golf tour operators, travel agencies, possibly PROs or golf clubs; according to Miснацкó's theory (2007), golf media also belongs to that sector).

The attraction, i.e. the golf course which represents the basis for golf tourism is basically a man-made attraction which blends into its environment to the greatest possible extent, and it provides an enjoyment via the best possible play, and it is organically linked to the natural, the social and the economic environment. That demand is the alpha and the omega of experience. It is indicative of the size of the intermediary sector that the International Association of Golf Tour Operators (hereinafter: IAGTO), the most significant professional organisation managing golf tourism established in 1997, has 2,057 members from 90 countries totally covering the travel sector.

Apart from 488 accredited golf tour operators from 61 countries, the association brings together golf courses, golf hotels, golf resorts, airlines, passenger transportation companies, tourism organisations, the media and their business partners. IAGTO sells $85 \%$ of the world's golf packages at a value of around USD 1 billion. They often tailor their programmes to the individual needs, since they have a vested interest in building up a pool of regular customers willing to visit other golf destinations, too.

The golf tourism supply is made up of the concurrent availability of several factors. Apart from the attraction mentioned above, in the major golf destinations, not only the existence of basic and tourism infrastructure is required, but also that of the primary and secondary suprastructure. In other words, apart from transport networks serving tourism (airports, transfer, car rental or shuttle services), there is a need for quality accommodation (special golf hotels, resorts), catering facilities (golf pubs and bars) and other supplementary services (golf shops, golf equipment retailers). The marketing of the tourism supply done by the regional destination management boards also plays an important role. Apart from the high standards of hygiene and security related to the quality services, demonstrating hospitability is equally important for both the golf clubs and the residents of the resort.

The outer system is the collection of interacting environmental factors each of which influences the operation of the market to varying degrees. The constant dynamism of these factors requires continuous adjustments from the system's intermediaries.

Being a factor adjusting to the individual needs, motivation plays an exceptional role in the research of tourism (AUBERT, A. 2011). Motivation manifests itself on different levels, and it is important to study its interpretation from the perspective of golf on the basis of Maslow's hierarchy (1979) of motivational needs (Figure 3).

- In the lowest level of the pyramid, one can differentiate between two groups of physiological needs: the biological needs related to golf (accom- 


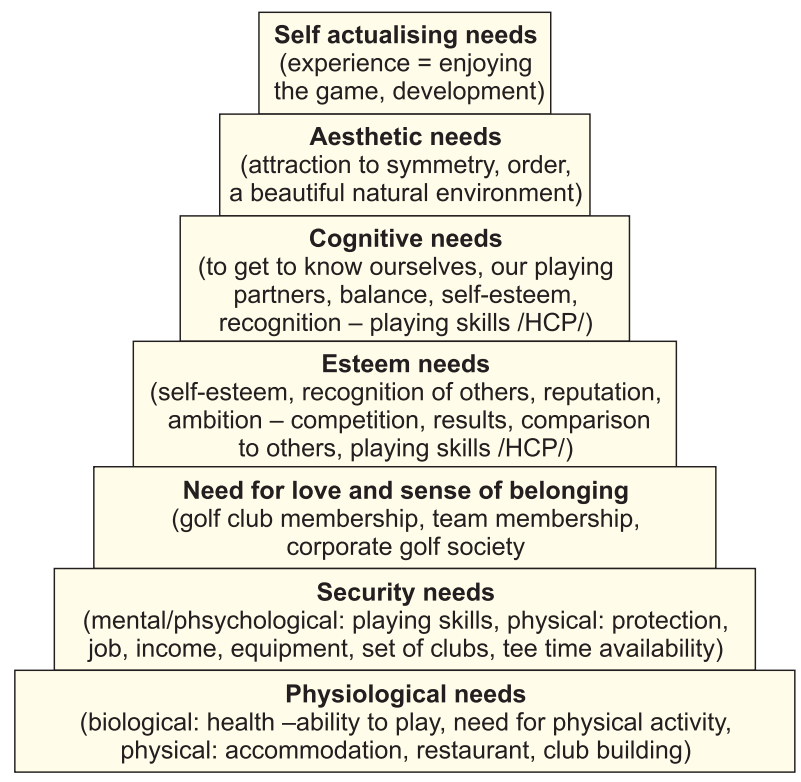

Fig. 3. Interpretation of Maslow's hierarchy of motivational needs from the perspective of golf (modified by Kiss, R. 2013)

modation and catering as well as a club house related to the game), while the other group includes a health-conscious way of thinking, the ability to play and the satisfaction of the needs for physical activity.

- The second level represents the need for security which after the satisfaction of the needs at the previous level can be further divided into two groups: psychological security means adequate and sure playing skills as well as problem-free playing opportunities with the required gear, while physical security means the availability of a job and income. A great advantage of private courses lies especially in the latter ones.

- The third level represents the need for love and the sense of belonging which is clearly satisfied for the members of a golf club. In case of competitions, it can be further reinforced by a team membership. It is also typical and has been mentioned in the theory part that corporate golf societies satisfy the need for belonging to a community similarly to a team-building training session.

- The fourth category represents the need for recognition as a team member, a balanced personality, which is mostly related to the quality of a golfer's performance. An image is formed about the golfer which becomes measurable on the basis of his playing skills $(\mathrm{HCP})$, and the better a golfer can play, the greater recognition he can hope for, irrespective of his weekday profession. In a developed golf society, there is no difference between golfers on the course: only the playing skills matter. 
- The fifth level represents cognitive needs, i.e. the need for golfers to get to know themselves and their fellow players, in which a great emphasis is given to a balanced personality, which can be the basis for a successful and an effective game.

- The sixth level is that of aesthetic needs including the pleasant geographical environment surrounding the golf courses, the interior design and the quality finish of a golf club, a golf hotel or a resort. They all indicate environment consciousness and the need for tidiness, as well.

- The seventh level (the peak of the pyramid) represents the need for self-actualisation through enjoying the game and skill development.

In line with the systemic approach, the most characteristic features of golf tourism as a tourism product are marked with the 4As taken from the international literature. The ' $\mathrm{A}$ ' mark of the tourism product can be replaced with ' $G$ ', since the proper terminology for each category begins with a ' $G$ '. So $4 \mathrm{As}$ corresponds to $4 \mathrm{Gs}$ as follows:

- Attraction = Golf course(s),

- Access $=$ Golf shuttle $/$ golf cruise / golf transfer,

- Accommodation $=$ Golf hotel $/$ golf resort,

- Attitude = Gentlemen's sport.

From the 4Gs of golf tourism, we must take the golf course as an "Attraction" first, since it represents the greatest appeal. It is the interest in the golf courses which puts millions of avid recreational players on the move. The appeal of a course is usually influenced by several factors, i.e. the difficulty (playability), the quality, the location, the environment, the physical accessibility, the price, the reputation as well as the design (layout) of the course in the case of more able golfers.

As far as the second G (golf shuttle, golf cruise) is concerned, "Access" (A) is an important factor when choosing a golf destination for two reasons. On one hand, the accessibility of the destination is important, therefore airlines ask already at the time of booking whether the customer intends to travel with a golf bag, i.e. unusual baggage. The distance between the golf course and the airport is an important criterion. On the other hand, it is a common practice to use local transport (shuttle buses) in case of group and individual travels alike (such services are ordered by the tour operator), however, a car rental is also an option for individuals. The shuttle transfer of group guests from the hotels to the golf courses is also of utmost importance, partly because golf tourists do not like long local trips and it is important that $3-5$ golf courses should be within 30-50 minutes drive from one another. Accessibility significantly increases customer satisfaction, therefore the positive reputation of the destination.

The third G is 'golf hotel, resort' as in "Accommodation" (A). It is a self-explanatory, organic part of the golf package. The hotels either belong to the golf course, or they are located nearby, and transfer between the two 
is provided by shuttle services as mentioned above. Golf courses are usually the destinations of quality tourism with high-end tourists in terms of needs and spending alike.

The fourth G represents 'gentleman' or "Attitude" (A). This factor is important, because the sport or the game itself requires fair play without a referee. The gentleman attitude is less visible in the developing destinations and in the emerging markets, and it is more difficult to establish it than in a country with golf traditions and culture. Yet, the real threat of being excluded by the golf community encourages golfers to observe the rules.

Following the above chain of thoughts, the author defines golf as a sport with another set of $4 \mathrm{Gs}$ as follows:

- Gorgeous/Great - unique experience,

- Game (on) - exciting game,

- Green,

- Grass.

Golf as a sport implies the passion for the game, humbleness and respect, since golf is an exciting outdoor activity providing enjoyment even when played without referees, simply on the basis of honesty, in a wonderful natural setting with calming colours. Table 2 summarises the product approach of golf tourism and the definition of golf sport.

Table 2. The $4 \mathrm{Gs}$ of golf tourism and golf sport

\begin{tabular}{l|l}
\hline \multicolumn{1}{c|}{ The 4Gs of golf tourism } & \multicolumn{1}{|c}{ The 4Gs of golf sport } \\
\hline Golf course & Gorgeous/Great \\
Golf shuttle / cruise & Game \\
Golf hotel/resort & Green \\
Gentleman & Grass \\
\hline
\end{tabular}

Source: KIss, R. 2013

A tourism product cannot exist without the material conditions, the development of which follows the proven steps of regional and tourism development. The prerequisite of service development is the availability of basic infrastructure: transport, utilities (electricity, gas and water supply, sewage system) and communications which can serve as a foundation for suprastructural investments (AUBERT, A. 2001). Resorts emerge as a result of the successive stages of implementation.

The peak or most significant stage of every scientific activity or research is independent modelling. The system of relationships of golf tourism as a tourism product, as well as that of the material conditions of tourism, is shown by the golf ball model (Figure 4).

The name of the model refers to the layered structure of the Earth as well as the layered interior of a golf ball. That parallelism is represented by the entirety of the interconnected basic, infra and suprastructural investments and 


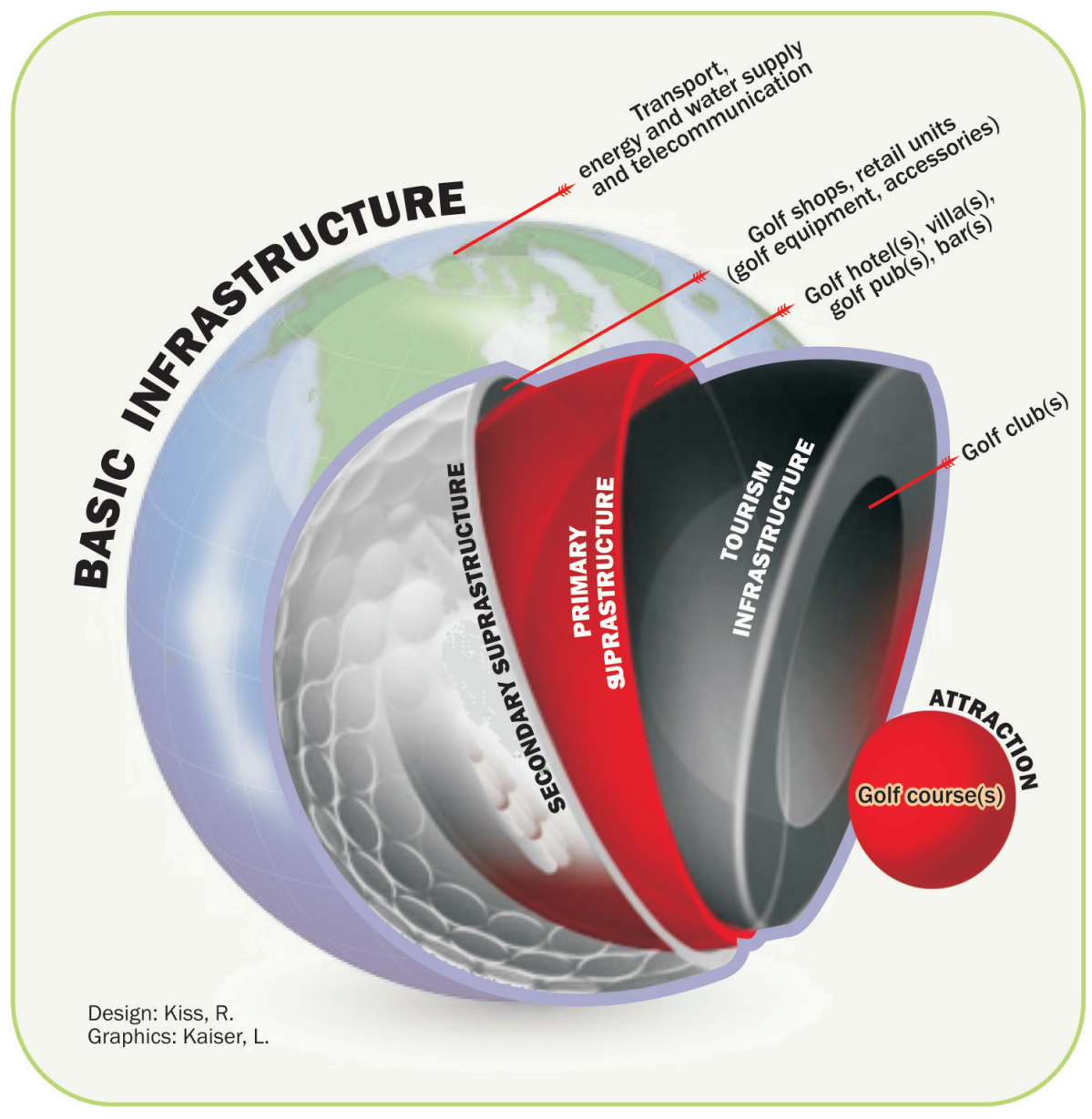

Fig. 4. The relationship between the material conditions of golf tourism as a tourism product and that of tourism on the basis of the golf ball model. Source: KIss, R. 2013

services which are held together by an outer solid crust (basic infrastructure) similarly to the Earth crust holds the deeper, malleable layers of the Earth.

If we translate the model into golf tourism, the golf course acts upon the golfer as the most important attraction (encourages travel). A significant investment project even a property based one starts with the construction of the course. The development of the surrounding tourism infrastructure (golf club), as well as that of the primary suprastructure (golf hotel, golf resort, golf buffet) and the secondary suprastructure (shops selling golf equipment and accessories) comes only afterwards. However, the model developed for the 
classic, mainly seaside golf destinations cannot be fully used for certain regions which are not specialised in golf (e.g. Hungary) only due to the larger distances between the individual courses as well as the underdeveloped primary and secondary suprastructural facilities.

Although the golf ball model can primarily be used to study seaside golf developments, it is also suitable to determine the extent to which golf tourism is present in a given region. Therefore, it is necessary to provide a short overview on the international expansion of golf.

\section{The geographical expansion of international golf tourism supply elements}

As far as the origin of the nowadays widespread golf is concerned, it is widely accepted that golf is a Scottish invention. According to this approach, in the $15^{\text {th }}$ century golf was played by shepherds on the undulating links in the southern coastal region of Firth of Forth, in an area of sand dunes. The author shares the opinion that golf has Scottish origins (1457) and there is no doubt that the etiquette of golf reflects Scottish and English influence, just like the appearance of gentlemen playing a sport based on fair play with no referee and observing the strict rules. The first golf course was built in Leith, Scotland in 1744. It was followed by the construction of the most renowned course in 1754 which was later named Royal \& Ancient Golf Club of St. Andrews (R\&A), and it is still regarded as the cradle of golf.

The geographic expansion of golf started in the $19^{\text {th }}$ century and it had accelerated by the $20^{\text {th }}$ century due to having been exported by colonisers as a popular recreational activity. The dynamics of the expansion can be detected mostly in the foundation of golf clubs, which illustrates the spatial expansion of Anglo-Saxon culture. The United States, Canada, Australia, the Republic of South Africa, as well as the British Isles are turned to be the most significant golf tourism markets, and at the same time, they are considerable factors on both the demand and supply sides of international tourism. As it can be seen in Table 3, nearly half of the world's golf courses are located in the United States, and nearly half of the world's golf players live there.

It is due to the fact that the North Atlantic economic power gradually shifted from Europe to North America, and in parallel with the strong industrialisation, the expansion of golf courses has also accelerated on the American continent since the 1890s. The process lasted until the 1920s, and forty years later a new boom started, primarily for two reasons:

- The state gave preference to the construction of inexpensive public golf courses to make golf a mass sport. That effort was facilitated by easily accessible bank financing supporting new investment projects. 
Table 3. The largest golf super powers in 2012

\begin{tabular}{l|l|c|c|c}
\hline Rank & Country & $\begin{array}{c}\text { Number of golf } \\
\text { courses }\end{array}$ & $\begin{array}{c}\text { Number of golfers, } \\
1,000 \text { people }\end{array}$ & $\begin{array}{c}\text { Ratio of the } \\
\text { number of courses } \\
\text { to the world total, } \%\end{array}$ \\
\hline 1 & USA & 17,000 & 27,000 & 50.0 \\
2 & Japan & 2,350 & 9,000 & 7.0 \\
3 & Canada & 2,300 & 1,500 & 7.0 \\
4 & England & 1,867 & 750 & 5.0 \\
5 & Australia & 1,500 &.. & 4.0 \\
6 & Germany & 716 & 624 & 2.0 \\
7 & France & 579 & 418 & 2.0 \\
8 & Scotland & 541 & 230 & 1.0 \\
9 & China & 500 &.. & 1.0 \\
10 & Sweden & 436 & 491 & 1.0 \\
\hline
\end{tabular}

.. = no data. Source: EGA 2013

- The emergence of media interest in professional golf tournaments, sponsorship.

Assisted golf course development reached its peak in the 1990s and property development remained in the focus in the areas suitable for recreational activities, since homes built around golf courses became very popular, especially in the southern states where buyers were willing to pay up to $30 \%$ more for such apartments, whether they played golf or not (KPMG 2008). However, since the 2000s the number of American and British golfers has been decreasing slowly, while certain European countries (Germany, Austria and Eastern Europe), as well as some Asian countries and cities (China, Dubai) have experienced a golf boom (KPMG 2010b).

A dynamic development similar to the one in the US could also be witnessed in Europe in the 1980s, since the Scandinavian countries, Germany, France and Spain joined Britain with significant investment projects. During that period, a growth of 40 to $60 \%$ could be registered (Figure 5). It resulted in the creation of special golf destinations in different versions around the world. Thus, we can differentiate among property development (residential parks in the US), the acquisition of a second home (Southern Europe) as well as golf resorts in exotic places (Dubai) (KPMG 2010b; Hudson, S. and Hudson, L. 2010). Southern European countries with a Mediterranean climate (Portugal, Spain and Turkey) aimed to extend the season by attracting golf tourists to facilities used by vacationers in the summer high season (KIss, R. 2012).

The concentration of the European golf supply is illustrated by Figure 5 which also shows that the level of golf in a given region is significantly influenced by the economic and social conditions. Therefore, it goes without saying that golf destinations include the Western countries (British Isles 30.9\%, 


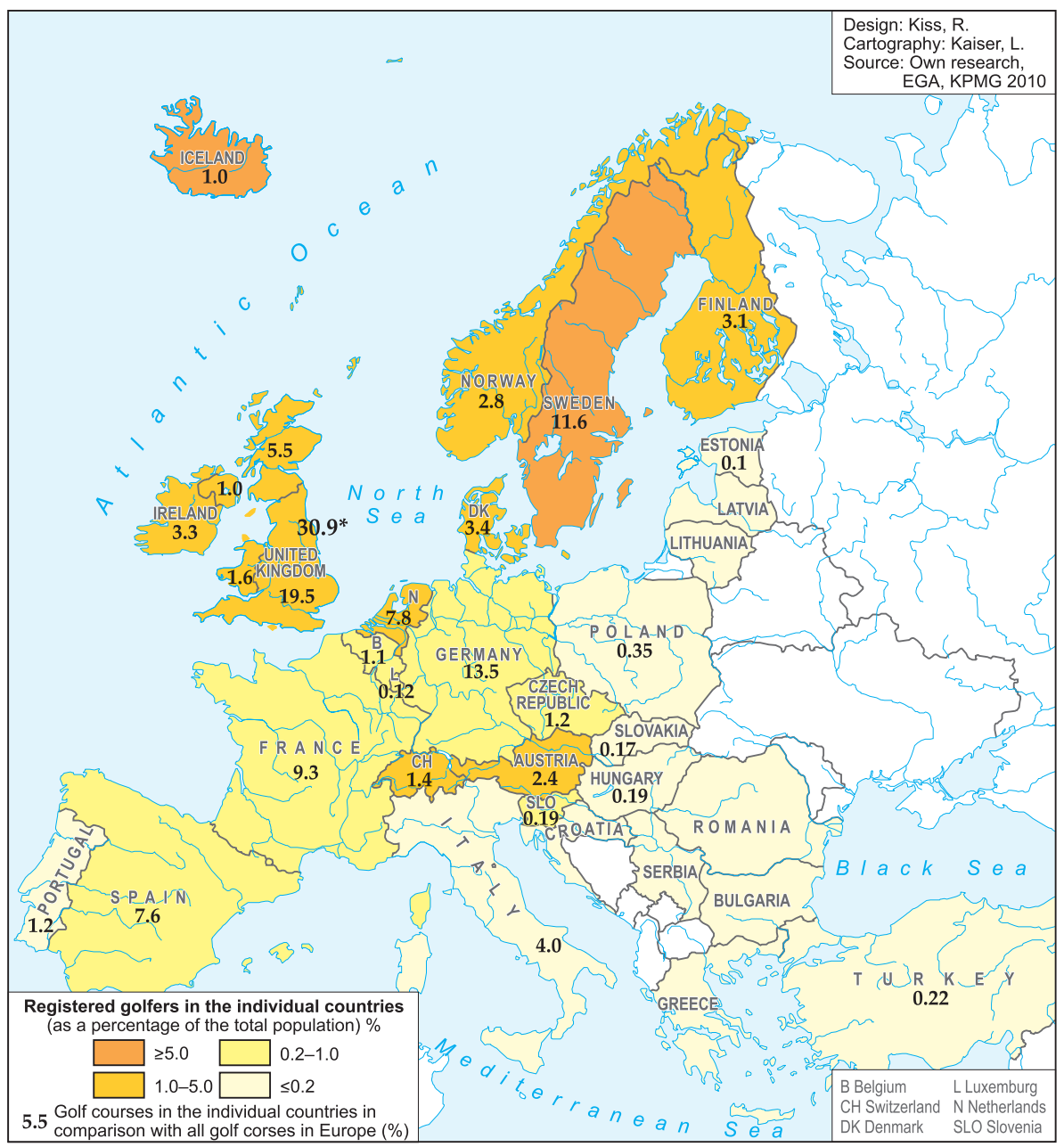

Fig. 5. The breakdown of major European golf destinations and the ratio of golf demand to the population of the individual countries. *Playing golf is not tied to registration in the British Isles (there are around 4 million golfers in the UK, approx. $7 \%$ of the total population). Source: KPMG 2010a, EGA 2013, KIss, R. 2013

Germany 13.5\%, Sweden $11.6 \%$, France 9.3\%, Spain 7.6\% and the Netherlands $7.8 \%$ ). The six countries account for $80.7 \%$ of the golf supply in Europe. Consequently, on the demand side the ratio of golfers to the whole population exceeds 1 to $5 \%$ in economically strong countries with a large population density, but also in Scandinavia which has a low population density.

The expansion of golf continued to the east on the continent, thus by the very beginning of the $20^{\text {th }}$ century it had reached the Austro-Hungarian 
Monarchy where several golf courses were built. Some of them survived the collapse of the empire, and they still exist thanks to the aristocracy, a strong middle class and wealthy people in general providing a sufficient base for sport, especially in the "eternal provinces" (Austria, Bohemia). All this is history. The fact that in the Eastern Bloc only the Czechs did not ban golf as an elite sport provides the Czech Republic a great advantage impossible to overcome.

In the Central European region, a significant development can be witnessed in Poland, Slovakia and Bulgaria. Poland and Bulgaria have excelled in golf course construction, while Slovakia has shown talent in the recruitment of golfers (KPMG 2010a). In comparison, following a promising start after the change of the political regime, Hungary's performance has been characterised by slowing growth, stagnation and more recently a decline. Therefore, due to the small supply and demand, it is continuously falling behind its neighbours in terms of competition (Table 4).

Table 4. Golf demand and supply in the countries of Central Europe in 2012

\begin{tabular}{l|c|c|c}
\hline \multicolumn{1}{c|}{ Country } & $\begin{array}{c}\text { Number of golf courses } \\
\text { (with 9, 18 or more holes) }\end{array}$ & $\begin{array}{c}\text { Share in the } \\
\text { European supply, \% }\end{array}$ & $\begin{array}{c}\text { Number of } \\
\text { golfers }\end{array}$ \\
\hline Austria & 156 & 2.40 & 104,732 \\
Czech Republic & 96 & 1.20 & 55,547 \\
Hungary & 15 & 0.19 & 1,419 \\
Poland* & 27 & 0.35 & 3,008 \\
Slovakia & 14 & 0.17 & 7,200 \\
Slovenia & 13 & 0.19 & 8,762 \\
Croatia** & 3 &.. & 550 \\
Serbia & 2 &.. & 618 \\
Romania** & 4 &.. & 551 \\
Bulgaria & 7 &.. & 639 \\
\hline$* 2012 * * 2010,=$ no data. Source KPMG 2010b, 2012; EGA 2013, KISS, R. 2013.
\end{tabular}

\section{Conclusions}

The geographical expansion of golf has been influenced by several concurrent processes, therefore, in addition to the level of the economic development of a golf centre, the social factors (the cultural background of the local population, the openness of people), as well as the political system and the openness of a country have also played a great role. In addition, the natural environment has been extremely important and just like in the expansion of tourism, it appeared as 'push' and 'pull' factors in certain popular regions with a pleasant climate (e.g. Mediterranean or subtropical).

The importance of golf tourism in the tourism industry can be measured by international standards; it plays an outstanding role in certain (golf) destinations. The appearance and the development of golf and tourism 
strongly depend on the climatic and geographic features of a region. The author has presented the geographical expansion of golf and the breakdown of the supply side within Europe. He also highlighted the strong correlation between the geographical expansion of golf and the current golf super-powers, indicating the social and economic acceptance of this sport.

The state-assisted development of golf as a tourism product supplementing mass tourism has proved to be successful, especially in the Mediterranean region of Europe. The coastal areas and islands primarily used by mass tourists have seen the emergence of supply elements used by golf tourists rather than vacationers in the low seasons. Consequently, the European Mediterranean region can be divided into A, B and C golf destinations.

In the system of golf tourism, the main travel motivation is the golf course itself therefore it was essential to prepare the hierarchy of golfers' needs following the classic example of Maslow's pyramid of needs. In the revised model, the author interpreted the relations between the individual levels from the golfers' perspective. As a result of further theoretical innovation, the 4As (most important characteristic features) of golf tourism known as a tourism product in the international literature was converted into 4Gs. It was inevitable to define golf tourism in the paper and the related research.

Following the systemic approach within his own research activities, the author established an independent model which is based on the basic model of the external and internal system of tourism, supplemented with the special features of golf in the form of a golf ball model. Since the interior structures of both the golf ball and the Earth are layered in spherical shells, the model is suitable for the illustration of the interconnection of the basic assumptions on tourism product development as well as that of the interactions among the material conditions of tourism product.

\section{REFERENCES}

Aubert, A. 2001. A turizmus és a területfejlesztés stratégiai kapcsolata Magyarországon (The relationship between tourism and regional development in Hungary). Turizmus Bulletin 5. (1): 44-49.

Aubert, A. 2011. Turizmus trendek és térszerkezet Magyarországon (Tourism trends and the spatial structure of tourism in Hungary). Pécs, Publikon Kiadó, 143 p.

BARÁth, K., SzÉLes, J. and KÁlmán, E. 2011. A magyar golf stratégiai és operatív terveinek változása az olimpiára készülve (Changes in the strategic and operative plans of Hungarian golf in preparation for the Olympic Games). Magyar Sporttudományi Szemle 12. (46): $22 \mathrm{p}$.

Correia, A. and Pintassilgo, P. 2006. 'The golf players' motivations: the Algarve case'. Tourism and Hospitality Research 6. (3): 227-238.

Csapó, J., Savella, O. and RemenYik, B. 2011. Aktív turizmus (Active tourism). In Turisztikai terméktervezés és fejlesztés. Ed. Michalkó, G., Pécs, University of Pécs, 266 p. 
EGA European Golf Association, 2013. Figures for 1991-2013. www.ega-golf.ch Hudson, S. and Hudson, L. 2010. Golf Tourism. Oxford, Goodfellow Publishing Ltd., 286 p. Kim, S.S., Chun, H. and Petrick, J.F. 2005. Positioning analysis of overseas golf tour destinations by Korean golf tourists. Tourism Management 26. 205-917.

KIss, R. 2012. A golfturizmus fejlesztésének hatásai a földrajzi környezetre a törökországi Belek térségében (The effects of golf tourism development on the geographical environment in the Belek region of Turkey). Földrajzi Közlemények 136. (2): 152-164.

KIss, R. 2013. A golfturizmus rendszere, a nemzetközi és hazai kereslet-kínálat trendjei és területi vetületei (The system of golf tourism, the trends and regional distribution of international and national supply and demand). Doctoral thesis. Doctoral School of Earth Sciences, Pécs, University of Pécs, 293 p.

Kiss, R. and RÁTz, T. 2007. Golf és turizmus - a magyarországi golfpályák összehasonlító elemzése (Golf and tourism - a comparative study of Hungarian golf courses). In Apáczai Napok 2006. Hagyomány és Fejlödés Nemzetközi Tudományos Konferencia. Tanulmánykötet I. Ed.: LőrINCZ, I., Győr, Nyugat-Magyarországi Egyetem Apáczai Csere János Kar, 347-364.

KPMG 2008. The Value of Golf to Europe, Middle East and Africa. Budapest, KPMG Advisory. Last download: 24.08.2012 www.golfbenchmark.com

KPMG 2010a. Country Snapshot: Poland. Budapest, KPMG Advisory. Last download: 13.03.2011 www.golfbenchmark.com

KPMG 2010b. Country Snapshot: United Arab Emirates. Budapest, KPMG Advisory. Last download: 13.03.2011 www.golfbenchmark.com

KPMG 2012. Golf participation in Europe 2011. Budapest, KPMG Advisory. Last download: 10.02.2012 www.golfbusinesscommunity.com/article/golf_participation_in_europe_2011

Lengyel, M. 1992. A turizmus általános elmélete (The general theory of tourism). Budapest, VIVA Advertising Agency, $212 \mathrm{p}$.

Michalкó, G. 2002. Az aktív turizmus elméleti megközelítése (A theoretical approach to active tourism). In Aktív turizmus. Ed.: DÁvid, L., Debrecen, Didakt Kiadó, 5-16.

Michalkó, G. 2007. A turizmuselmélet alapjai (The foundations of tourism theory). Székesfehérvár, Kodolányi János College, 224 p.

Petrick, J.F., Backman, S.J., Bixler, R. and Norman, W.C. 2001. Analysis of Golfer Motivations and Constraints by Experience Use History. Journal of Leisure Research 33. (1): 56-70.

RÁTz, T. and KIss, R. 2007. A golfozás mint aktív turisztikai tevékenység Magyarországon (Golf as an active tourism pastime). Magyar Sporttudományi Szemle 7. (27): 22-26.

Rátz, T. and Kiss, R. 2010. The Attitudes and Activities of Hungarian Golfers: An Analysis of Domestic Demand. In III. International Conference "The Role of Tourism in Territorial Development". Eds.: Dombay, S. and Magyari-Sáska, Zs., Cluj-Napoca, Presa Universitară Clujeană, 291-305.

Robinson, T. and Gammon, S. 2004. Sports Tourism: An Introduction. London, Thompson Learning, $248 \mathrm{p}$.

Szonda Ipsos 2000. A felnőtt lakosság véleménye az aktív üdülési és kulturális tevékenységekről (Opinion of the adult population on active holiday and cultural programmes). Turizmus Bulletin 4. (4): 38-41.

Wilson, J. and Thilmany, D. 2006. Golfers in Colorado: the role of golf in recreational and tourism lifestyle and expenditures. Journal of Travel $\mathcal{E}$ Tourism Marketing 20. (3-4): 127-144. 